British research

\section{Politicians also ask for more}

THE British House of Commons Committee that serves as a watchdog for Sir Keith Joseph, Secretary of State for Education and Science, said all the right things last week about the needs of British science. But there can be no assurance that its recommendations will be in time or weighty enough to influence the budget process for the next financial year, now under way

The select committee's report The Future of the Science Budget (HMSO) explains that the enquiry on which it is based had been begun as a "short general introduction" to the role of the Department of Education and Science in the support of research, but that the committee was persuaded, during its work, that there is substance in present concerns about the condition of British science.

Some of the committee's suggestions for change are novel, at least in the sense that they could be taken over virtually unchanged in the construction of the British government's budget for $1986-87$. Thus the committee, noting that the total science budget, now $£ 583$ million a year, is spent largely by the research councils, suggests that the cost of paying superannuation contributions for the full-time members of their staffs should be separate from the science budget itself. The committee argues that superannuation costs are an inescapable but rising burden on

\section{Auto-lobbying}

The Parliamentary and Scientific Committee of the British Parliament (Lords plus Commons) is doing what it can to make its work more pointed. A cross between a dining club and a voluntary caucus from whose meetings the press is religiously excluded, the committee has now appointed Sir Gerald Vaughan as the chairman of a ginger group that will attempt to identify important issues in the administration of science and to win a parliamentary hearing for them.

The main committee has always been a potentially valuable forum for this purpose, but the general meetings tend to follow rather than lead to important issues, and their privacy muffles their effect. Vaughan thinks that he and his small group of parliamentarians (for which Dr John Bleeby, director of a Medical Research Council unit at Carshalton. Surrey, will serve as convenor) will be able to identify emerging issues in good time. The group's first meeting, he explains, held a long discussion about continued British membership of CERN, and was persuaded that the issue deserves parliamentary attention. In this and other fields, Vaughan hopes, his group will become a lightning rod for the anxieties of the scientific community.

John Maddox the research councils (an estimated $£ 27$ million in the current financial year).

Among the committee's other proposals are the following:

- Research councils should be compensated for the costs of closing laboratories and paying off staff if government departments cancel research commissions with council institutes, and that there should be retrospective payments to take account of the upheavals of the past few years.

- The major part of the cost of international subscriptions (as, for example, to CERN) should be borne by government departments (such as the Foreign and Commonwealth Office) rather than the research councils, on the grounds that the subscriptions are required by international obligations from which the research councils could not unilaterally withdraw.

- For the time being, the real rate of growth of the British science budget should be 3 per cent above inflation.

- The Advisory Board for the Research Councils (ABRC) and the Advisory Council on Applied Research and Development (ACARD), respectively responsible for cutting the science budget cake and for giving the British government and the public miscellaneous advice on scientific matters, should be merged.

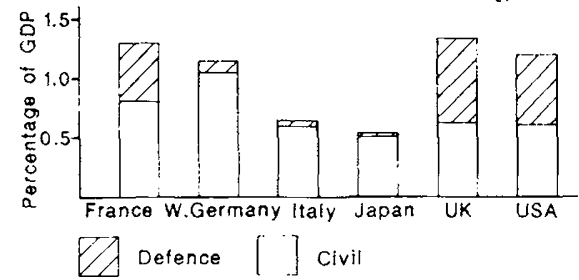

In the last of these recommendations, the committee follows the House of Lords Committee, which reported in 1981 , but does not go so far as to repeat that committee's recommendation that there should be a part-time minister for science. That, the committee says, would have required a full-scale enquiry, and "at this time we believe the main priority to be funding, not structure"

Interestingly, the House of Commons committee also shrinks from full endorsement of the idea that university budgets should be selectively determined (by the University Grants Committee), concentrating funds on universities or departments strong in research. The committee accepts Sir Keith Joseph's view that selectivity will entail "significant problems of judgement", and asks that the "dualsupport system should not be undermined or weakened". But it agrees that there should be better coordination between the grants committee and the research councils on the provision of equipment.

The committee seems to have been impressed by comparisons between the state of affairs in Britain and elsewhere (see chart), although it acknowledges the diffi-

\section{More US funds for AIDS \\ Washington}

THE US Secretary of Health and Human Services, Mrs Margaret Heckler, has responded to congressional pressure about AIDS (acquired immune deficiency syndrome) by adding $\$ 41$ million to the budget proposed for 1986. The increase, which has been found by shifting funds from other public health programmes, will go to support community health education and studies of the epidemiology and natural history of the AIDS virus by the National Institutes of Health (NIH) and the Centers for Disease Control (CDC). The total now proposed for combatting AIDS is \$126.3 million in the year from October 1985, an increase of almost 20 per cent.

The AIDS budget has been the target of a relentless campaign by Congressman Henry Waxman, the chairman of a subcommittee in the House of Representatives with oversight responsibility for the Public Health Service. The administration's original AIDS budget proposal of $\$ 85.5$ million for next year would have meant a substantial decrease. Waxman has complained that Secretary Heckler rejected proposals by public health officials for an increased budget because of an ideological decision to freeze spending. The administration's revised proposal, which was made only after Waxman threatened to subpoena internal department documents, will now be considered by appropriations subcommittees.

New activities proposed include: a follow-up study of blood donors who are found positive by the screening test for HTLV-III (human T-lymphotropic virus type III) and studies of new HTLV-III tests, to be carried out by the Food and Drug Administration; studies of the incidence of HTLV-III in selected areas and routes of transmission, to be conducted by CDC; $\$ 14$ million for health education in cooperative agreements with individual states; and studies both of epidemiology and of possible diagnostic and therapeutic agents by the NIH.

Tim Beardsley

culty of making comparisons between figures from different sources. It also points out that while the direct cost of the science budget has remained constant (or has slightly increased in recent years), indirect support, largely in the form of research commissions, has declined by roughly 10 per cent in real terms since 1981-82.

For the immediate future, the committee argues that basic research is essential for a modern industrial state, that the British government should accord it a higher priority, that academically-based research as in Britain has the particular virtue of uniting teaching and research, that the need to increase the science budget is "urgent" and that, by default, the "government will not achieve its own objective of maintaining the level of research". 